\title{
Co-infection by a yeast-like organism in Hematodinium-infected European edible crabs Cancer pagurus and velvet swimming crabs Necora puber from the English Channel
}

\author{
G. D. Stentiford*, M. Evans, K. Bateman, S. W. Feist \\ Centre for Environment, Fisheries and Aquaculture Science (CEFAS), Weymouth Laboratory, Barrack Road, The Nothe, \\ Weymouth, Dorset DT4 8UB, United Kingdom
}

\begin{abstract}
During the winter months, edible crabs Cancer pagurus and velvet swimming crabs Necora puber from the English Channel can harbour infections by a Hematodinium sp. dinoflagellate. This parasite is responsible for a highly pathological condition known as 'Pink Crab Disease' (PCD) in the edible crab. In the current study, a high proportion (between 25 and 100\%) of Hematodinium-infected edible and velvet swimming crabs captured from 2 sites in the English Channel also harboured a systemic infection by a yeast-like organism. This is the first report of such an infection in crabs. Budding yeast-like cells were observed intracellularly in circulating haemocytes and free in the host plasma. These cells stained positively with silver and periodic acid-Schiff (PAS) reactions. Despite an apparent haemocytopoenia in Hematodinium-infected crabs, haemocytic encapsulation of yeast-like cells was evident, while no such response was observed against Hematodinium sp. plasmodia. It is hypothesised that Hematodinium infection in these crabs may either increase the likelihood of secondary infections via an indirect suppression of the host immune system, or alternatively, decrease the likelihood of competitive growth inhibition by stimulating the host immune system to encapsulate and destroy secondary pathogens. Results are discussed with regard to the likely identity of the yeast-like organism, and the role of secondary pathogens in the eventual mortality of Hematodinium-infected hosts.
\end{abstract}

KEY WORDS: Cancer pagurus · Haemocytes · Hematodinium · Immunosuppression · Necora puber · Secondary infection · Yeast

Resale or republication not permitted without written consent of the publisher

\section{INTRODUCTION}

Edible crabs Cancer pagurus and velvet swimming crabs Necora puber both support important fisheries in European waters. C. pagurus captured from various sites within the English Channel can harbour infection by a parasitic dinoflagellate of the genus Hematodinium (Latrouite et al. 1988) that causes severe pathological alterations to the organs and tissues (Stentiford et al. 2002). A similar parasite, also described infecting $N$. puber, is suspected of causing a major collapse of a once lucrative fishery in French coastal waters (Wilhelm \& Mialhe 1996). Hematodinium-like organisms have also been reported from several other commercially important crustacean species from around the world (Newman \& Johnson 1975, Maclean \& Ruddell 1978, Meyers et al. 1987, Field et al. 1992, Hudson \& Lester 1994, Hudson \& Shields 1994, Messick 1994, Taylor \& Khan 1995, Wilhelm \& Mialhe 1996).

In addition to environmental stressors such as pollution (Houghton \& Matthews 1986, Ross et al. 1996), and those associated with handling and transportation (Johnson 1983), pathogens can impose significant bio- 
chemical and physiological stresses upon their hosts (Thompson 1983). Studies of Hematodinium sp. infections in decapod crustaceans have shown that during severe patent infections, the concentration of plasma haemocyanin and the number of circulating haemocytes are reduced concomitant with increasing parasite burden (Field et al. 1992, Field \& Appleton 1995, Taylor et al. 1996, Shields \& Squyars 2000). The resulting hypoxia leads to acidosis of the tissues and an altered hormonal status of the host (Stentiford et al. 2001). The biochemical composition of the haemolymph and tissues is also altered to reflect the considerable physiological stresses being imposed by the parasites on their hosts (Stentiford et al. 1999, 2000). It is expected that under such conditions, the normal crustacean 'immune' processes of wound repair, induction of the prophenoloxidase system, clotting, phagocytosis and encapsulation of foreign material would be unlikely to occur (Sindermann 1971, Johnson 1980, Smith \& Söderhäll 1986, Smith \& Chisholm 1992, Thörnqvist \& Söderhäll 1997).

A number of studies have reported the occurrence of secondary bacterial infections in invertebrates, particularly for virus-infected crustaceans under aquaculture conditions (Arcier et al. 1999). In such cases, secondary infections are generally attributed to immunosuppression induced by the primary pathogen (Johnson 1983). Secondary infections, some of which are likely to be caused by opportunistic pathogens, have also occurred in Hematodiniuminfected hosts. Bacteraemia was reported in the haemolymph of Hematodinium-infected tanner crabs Chionoecetes bairdi (Meyers et al. 1987), and bacteria are often found within the fixed phagocytes of the hepatopancreas of Hematodinium-infected Nephrops norvegicus (G. D. Stentiford pers. obs.). Other pathogens, such as an unidentified ciliate parasite, have also been reported in Hematodinium-infected crabs (Meyers et al. 1987).

This paper describes an infection by a yeast-like organism in Hematodinium-infected Cancer pagurus and Necora puber captured from various sites within the English Channel. As such, it is the first description of a yeast infection in crabs. Histopathological changes are discussed in relation to the likely opportunistic nature of this yeast co-infection in Hematodiniuminfected crabs, the possible effects of Hematodinium on the host immune system, and the role that such secondary infections may play in the morbidity and mortality of the host. Furthermore, it provides an example of how opportunistic pathogens can exploit the weakened immune system of crustaceans during stressful episodes, and may be a useful model for studying the development and pathogenesis of disease under such conditions.

\section{MATERIALS AND METHODS}

European edible crabs Cancer pagurus and velvet swimming crabs Necora puber were captured from the south coast of Guernsey (UK Channel Islands; $49^{\circ} 24^{\prime} \mathrm{N}$, $2^{\circ} 32^{\prime}$ to $2^{\circ} 43^{\prime} \mathrm{W}$ ) and from Newton's Cove, Weymouth, UK ( $\left.50^{\circ} 34^{\prime} \mathrm{N}, 2^{\circ} 22^{\prime} \mathrm{W}\right)$, between December 2001 and February 2002 using conventional baited parlour pots. Sixteen Hematodinium-infected C. pagurus were sampled from the Guernsey site, while 120 C. pagurus and 120 N. puber, both with unknown status of Hematodinium infection, were sampled from the Weymouth site.

Histopathology. Crabs were anaesthetised by chilling to $4^{\circ} \mathrm{C}$ for $30 \mathrm{~min}$. The hepatopancreas, heart, gill, midgut, gonad, body muscle and claw muscle were removed from apparently healthy crabs and from those showing signs of Hematodinium sp. infection (Stentiford et al. 2002). Excised samples were placed immediately into Davidson's seawater fixative (Hopwood 1996) for $24 \mathrm{~h}$ before transfer to $70 \%$ industrial methylated spirit for transport and storage. All samples were processed for histological examination within $7 \mathrm{~d}$ of collection using standard protocols. Sections were stained with haematoxylin and eosin (H\&E) and selectively, re-sectioned material was stained with periodic acid-Schiff (PAS) and Grocott-Gomori silver stains. All stained sections were analysed by standard light microscopy and digital images were captured using the Lucia ${ }^{\mathrm{TM}}$ Screen Measurement System (Nikon).

Electron microscopy. Crab tissues excised for histology were also preserved for electron microscopy. Small blocks of tissue $\left(2 \mathrm{~mm}^{3}\right)$ were fixed in $2.5 \%$ glutaraldehyde in $0.1 \mathrm{M}$ sodium cacodylate buffer $(\mathrm{pH} 7.4)$ and $1.75 \%$ sodium chloride for $2 \mathrm{~h}$ at room temperature. Fixed tissue samples were rinsed in $0.1 \mathrm{M}$ sodium cacodylate buffer with $1.75 \%$ sodium chloride ( $\mathrm{pH} 7.4$ ) and post-fixed for $1 \mathrm{~h}$ at $4^{\circ} \mathrm{C}$ in $1 \%$ osmium tetroxide, reduced with $1.75 \%$ potassium ferrocyanide in $0.1 \mathrm{M}$ sodium cacodylate buffer. Specimens were washed in 3 changes of $0.1 \mathrm{M}$ sodium cacodylate buffer and stained en bloc in $0.5 \%$ aqueous uranyl acetate for $1 \mathrm{~h}$. Specimens were embedded in epoxy resin 812 (Agar Scientific-pre-mix kit 812) following dehydration through a graded acetone series. Thick sections were stained with Toluidine Blue for viewing with a light microscope to identify suitable target areas. Ultra thin sections (70 to $90 \mathrm{~nm}$ ) of these areas mounted on uncoated copper grids and stained with uranyl acetate and Reynolds' lead citrate (Reynolds 1963) were examined using a JEOL 1210 transmission electron microscope.

\section{RESULTS}

The pathological manifestation of Hematodinium sp. infection in Cancer pagurus has recently been 
described by Stentiford et al. (2002). Similarly, Wilhelm \& Mialhe (1996) provided a description of Hematodinium sp. infection of Necora puber. Of the 240 crabs sampled from the Weymouth site, 4 of 120 C. pagurus $(3.03 \%)$ and 1 of 120 N. puber $(0.83 \%)$ were shown to be infected with Hematodinium sp. using standard histological techniques as described below. Among the Hematodinium-infected C. pagurus captured from the Weymouth site, $2(50 \%)$ were co-infected with a yeast-like organism. The 1 Hematodinium-infected $N$. puber captured from the Weymouth site, was also co-infected with a yeast-like organism. Among the 16 Hematodinium-infected $C$. pagurus sampled from the Guernsey site, 4 (25\%) harboured infection by a yeast-like organism. Only crabs (of both species) that were infected with Hematodinium sp. harboured co-infection by the yeast-like organism.

\section{Histopathology of yeast-like infection}

The haemal sinuses of the hepatopancreas of coinfected crabs of both species were congested with large haemocytic encapsulations, outside of which were masses of Hematodinium sp. parasitic cells (Fig. 1). While no obvious host reaction appeared to be associated with the dinoflagellate, there was a host reaction associated with large numbers of small, ovoid yeast-like cells $(4.14 \pm 0.06 \times 2.68 \pm 0.03 \mu \mathrm{m}$, $\mathrm{n}=50$ ), some of which appeared to be in a state of division (budding). These cells stained positively with both PAS (Fig. 2) and Grocott-Gomori silver stains (Fig. 3) and were present as free cells (Fig. 4) and as large masses of free cells, some of which were apparently budding, in the haemolymph surrounding the hepatopancreatic tubules and in the sinuses of other organs and tissues (Fig. 5). In addition to masses of Hematodinium sp. parasitic cells, haemolymph smears contained large numbers of free ovoid cells that corresponded to the freestages described above. Under phase-contrast microscopy, these cells appeared refractile and were easily distinguished from the other cell types present.

Other histological features detected in infected crabs included the presence of abundant secretory packets within the B-cells of the hepatopancreas tubules (Fig. 6), the appearance of granuloma-like inflammatory reactions and tubular degeneration within the hepatopancreas, and similar melanised encapsulation responses within the gill lamellae and the connective tissue of the midgut wall (Fig. 7). Filamentous bacteria fouled the external surface of the gill epithelium of all infected crabs (Fig. 8).

\section{Ultrastructure}

Individual and budding yeast-like cells were present in the haemolymph of the tissue interstices (Fig. 9) as well as phagocytosed within the haemocytes (Fig. 10). Yeast-like cells were surrounded by an electron lucent 'halo' that separated the cell wall from the surrounding host material (Fig. 10). This 'halo' effect may have been caused by the presence of some unidentified extracellular coating of the yeast-like cell, or alternatively, due to shrinkage of the material during fixation. The cell wall consisted of 3 layers; a dark electron dense layer surrounding the cytoplasm $(20 \mathrm{~nm})$, a darker and thicker electron dense outer layer $(30 \mathrm{~nm})$ and a lighter electron transparent layer (60 $\mathrm{nm}$ ) separating these 2 layers. Nuclei and mitochondria were identified within the granular cytoplasm. Cristae were clearly visible within the mitochondria, especially in mature cells, which also contained vacuoles and lipid inclusions (Fig. 11).

\section{DISCUSSION}

Although Metschnikoff (1884) is considered to have initiated the discipline of invertebrate pathology with his studies on the invasion and subsequent phagocytosis of yeast-like cells in Daphnia magna (Bang 1983), there have been few subsequent descriptions of yeast-like infections in crustaceans. To date, yeast infections in crustaceans have been described from the Copepoda (Metschnikoff 1884, Pixell-Goodrich 1928, Unestam 1973, Codreanu \& Codreanu-Balcescu 1981), the Isopoda (Hyniewiecka-Szyfter \& Babula 1996, 1997a,b, Hyniewiecka-Szyfter et al. 1994) and prawns (Colorni \& Diamant 1992, Chen et al. 1994, Hsu \& Liu 1994, Lu et al. 1997, 1998, Chen et al. 2001). The current study provides the first documented description of a yeast-like infection in crabs.

Yeast-infected crabs (Cancer pagurus and Necora puber) were all found to be co-infected with the dinoflagellate parasite Hematodinium sp., previously described as causing 'Pink Crab Disease' (PCD) in $C$. pagurus from the English Channel (Stentiford et al. 2002) and similar Hematodinium sp. infections in numerous other crustacean species worldwide (Newman \& Johnson 1975, Maclean \& Ruddell 1978, Meyers et al. 1987, Field et al. 1992, Hudson \& Lester 1994, Hudson \& Shields 1994, Messick 1994, Taylor \& Khan 1995, Wilhelm \& Mialhe 1996). Since no crabs were observed to be infected only by the yeast-like organism, we suggest that it is an opportunistic pathogen, possibly exploiting the weakened immune system of the host crab, a feature known to accompany Hematodinium sp. infections in numerous crustacean species 


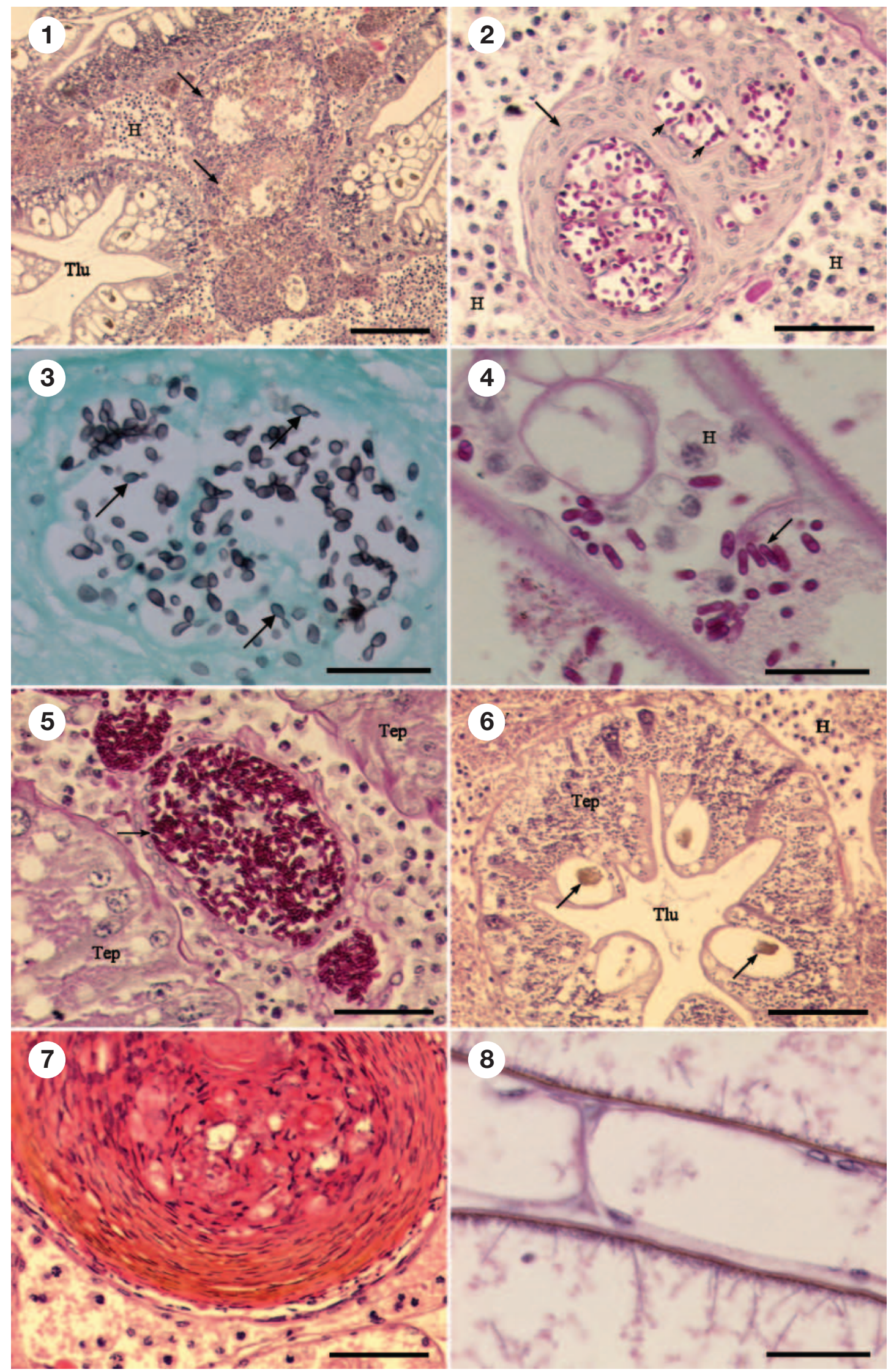


Figs 1 to 8 Hematodinium sp. infecting crab. Fig. 1. Hepatopancreas of Cancer pagurus infected with Hematodinium sp. and a yeast-like organism. Tubules with normal lumens (Tlu) were surrounded by masses of Hematodinium sp. cells (H). Inflammatory (encapsulation) reactions were seen only in relation to yeast cells (arrows) and caused blockage of haemal sinuses. H\&E stain, scale bar $=200 \mu \mathrm{m}$. Fig. 2. Haemal sinus of C. pagurus infected with Hematodinium sp. and a yeast-like organism. Haemocytes (long arrow) form encapsulations around yeast cells, some of which were in the process of budding (short arrows). No host reaction was associated with Hematodinium sp. cells $(\mathrm{H})$. PAS stain, scale bar $=50 \mu \mathrm{m}$. Fig. 3 . Haemocytic encapsulation response to yeast-like cells, some of which are in the process of budding (arrows). Grocott-Gomori silver stain, scale bar $=25 \mu \mathrm{m}$. Fig. 4. Gill lamellae of Necora puber infected with Hematodinium sp. and a yeast-like organism. Free stages of the yeast (arrow) and Hematodinium sp. plasmodia $(\mathrm{H})$ were seen in the haemolymph. Bacterial growth was common on the outer surface of the gill. PAS stain, scale bar $=25 \mu \mathrm{m}$. Fig. 5. Haemal sinus of C. pagurus infected with Hematodinium sp. and a yeast-like organism. Note the mass of yeast-like cells (and occasional Hematodinium sp. plasmodia) within the vessel (arrow) and the presence of Hematodinium sp. cells and free yeast cells in the haemal sinus. Normal tubule epithelial cells (Tep). PAS stain, scale bar $=50 \mu m$. Fig. 6. Hepatopancreas of C. pagurus infected with Hematodinium sp. and a yeast-like organism. Tubule epithelium (Tep) and lumen (Tlu) appear normal, though secretory packets were frequent within B-cell vacuoles (arrow). Free yeast-like cells (Y) and Hematodinium sp. plasmodia $(\mathrm{H})$ are present in the haemal sinuses. H\&E stain, scale bar $=100 \mu$ m. Fig. 7. Large granuloma in the gut wall of $N$. puber infected with Hematodinium sp. and a yeast-like organism. Free plasmodial stages of Hematodinium sp. can be seen outwith the granuloma. H\&E stain, scale bar $=50 \mu \mathrm{m}$. Fig. 8. Gill lamellae showing epibiotic growth of filamentous bacteria. PAS stain, scale bar $=25 \mu \mathrm{m}$

(Meyers et al. 1987, Field et al. 1992, Field \& Appleton 1995, Shields \& Squyars 2000, Stentiford et al. 2002).

The pathology accompanying co-infection was severe, with congestion of the haemal sinuses by masses of Hematodinium sp. plasmodia and yeast-like cells. Haemocytopoenia has been observed in numer-

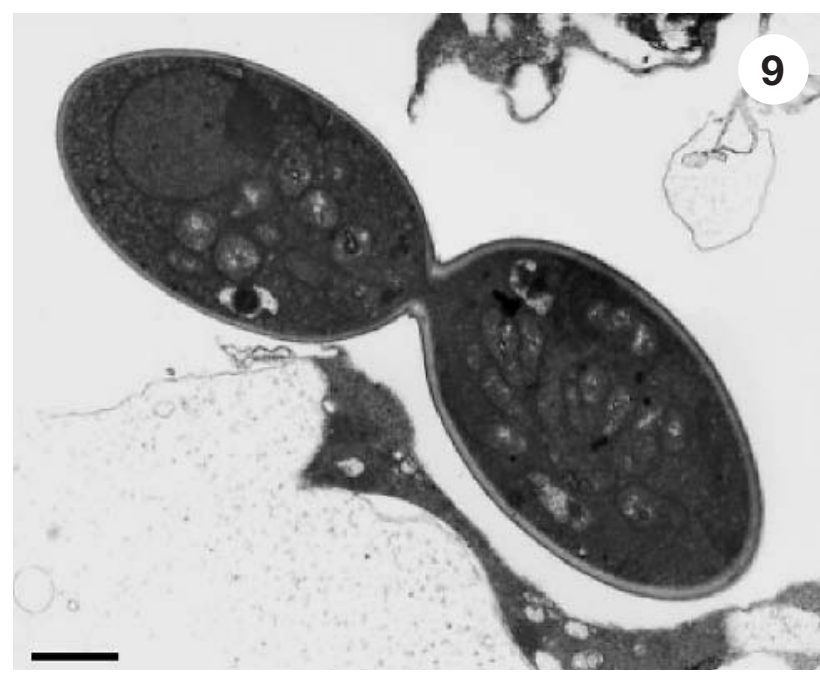

Figs. 9 to 11. Hematodinium sp. infecting Cancer pagurus. Fig. 9. Budding yeast-like cell in the haemolymph of a crab also infected with Hematodinium sp. Transfer electron microscope, scale bar $=1 \mu \mathrm{m}$. Fig. 10. Yeast-like cells phagocytosed within a host haemocyte. Yeast cells were surrounded by an electron-lucent 'halo' that separated the yeast cell wall from the surrounding host material. Transfer electron microscope, scale bar $=1 \mu \mathrm{m}$. Fig. 11. Mature yeast-like cell in the haemolymph. The cell wall consisted of 3 layers; a dark electron-dense layer surrounding the cytoplasm $(20 \mathrm{~nm})$, a darker and thicker electron-dense outer layer $(30 \mathrm{~nm})$, and an electron lucent layer $(60 \mathrm{~nm})$ separating the 2 . Nuclei, mitochondria, vacuoles and lipid inclusions were visible in the granular cytoplasm. Transfer electron microscope, scale bar $=1 \mu \mathrm{m}$ ous coelozoic bacterial and protistan infections of crustaceans (Johnson 1983). Accordingly, previous studies on Hematodinium-infected hosts have shown a marked reduction in the circulating haemocyte count concomitant with an increasing parasite burden (Field et al. 1992, Field \& Appleton 1995, Shields \& Squyars 2000).

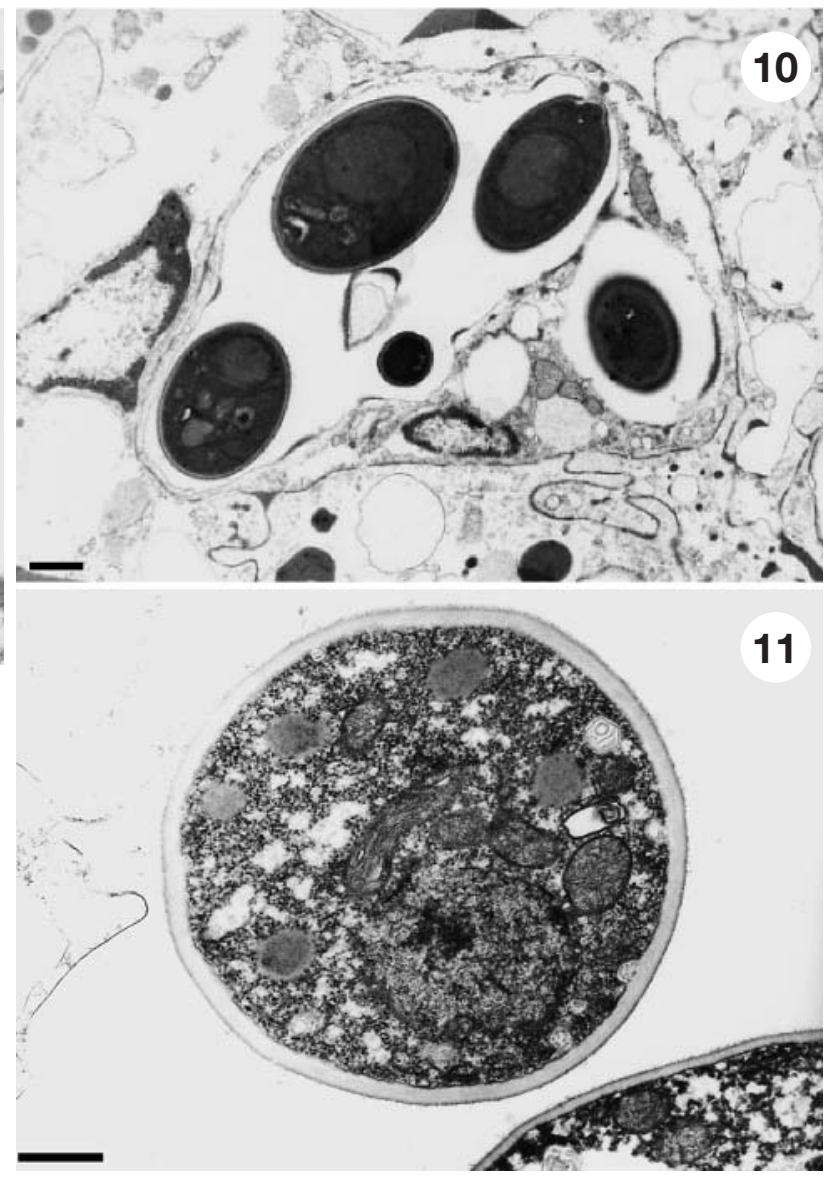


In the current study, while free haemocytes were not common in the haemolymph of co-infected crabs, and no apparent inflammatory responses were directed towards Hematodinium sp. cells, large encapsulation responses were associated with the yeast-like cells (Pixell-Goodrich 1928). Yeast cells were also observed within the cytoplasm of free haemocytes. Granulomalike lesions similar to those described by Sparks (1980) were also present, particularly in the connective tissue surrounding the midgut. These features suggest that the remaining immune function in these hosts was not directed towards the Hematodinium parasites but against the yeast-like cells. It is plausible that the crabhost immune system does not recognise the Hematodinium sp. cell wall as non-self. Numerous studies have shown that the prophenoloxidase system in crustaceans can be initiated by microbial cell wall components, such as $\beta 1$, 3-glucans in fungi and lipopolysaccharides and peptidoglycans in Gram-negative and Gram-positive bacteria, respectively (Thörnqvist \& Söderhäll 1997). It appears likely that the immune system of Hematodinium-infected hosts may still be able to respond to secondary pathogens, such as the yeastlike organisms, that express suitable stimulatory molecules in their cell walls. This host non-recognition of Hematodinium sp. infections is likely to play a key role in the pathogenesis of this disease, and may help to explain the abundance and rapid proliferation of Hematodinium cells within the haemolymph of infected hosts (Newman \& Johnson 1975, Maclean \& Ruddell 1978, Meyers et al. 1987, Field et al. 1992, Hudson \& Lester 1994, Hudson \& Shields 1994, Messick 1994, Taylor \& Khan 1995, Wilhelm \& Mialhe 1996, Stentiford et al. 2002).

Host recognition of the yeast-like cells also suggests that despite a reduction in the circulating haemocyte count in Hematodinium-infected crabs, the ability for host production and release of haemocytes in response to other pathogens may not be compromised and indeed may even be stimulated. A similar hypothesis has been associated with Hematodinium infection in Nephrops norvegicus whereby heavily infected host lobsters had enlarged haemopoietic tissues with elevated numbers of differentiating cells, mitotic figures and stem cell activity (Field \& Appleton 1995). It was further hypothesized that while infection led to increased haemopoietic activity, any increase in haemocyte cell number was likely to have been negated by the increased presence of haemocytic nodules in these animals. While haemocytic nodules have been reported in the tissues of Hematodinium sp.-infected C. pagurus, it has not been shown whether these nodules were associated with plasmodia of the Hematodinium sp. parasite or to some other unidentified pathogen (Stentiford et al. 2002). It may be possible to eliminate Hematodinium sp. parasites as the cause of these encapsulation responses by demonstrating the absence of haemocytic nodules in severely infected crabs. As such, it is possible that Hematodinium infection may even stimulate the immune system of infected hosts, thereby ensuring that secondary pathogens, which may ultimately compete with the primary pathogen for host resources, are encapsulated and destroyed. Additional challenge studies using a suitable secondary pathogen, coupled with detailed histological analysis of host tissues, may elucidate the precise relationship between the Hematodinium spp. parasites and the immune system of their hosts.

Because all material used in the current study was fixed prior to the discovery of the yeast-like co-infection, it was impossible to culture and identify the yeast species responsible for the infection in Cancer pagurus and Necora puber. Previous studies have identified a number of yeasts that infect crustaceans, including Metschnikowia (Metschnikoff 1884, Unestam 1973, Codreanu \& Codreanu-Balcescu 1981), Cryptococcus (Pixell-Goodrich 1928, Spencer et al. 1964, Unestam 1973, Hyniewiecka-Szyfter et al. 1994, HyniewieckaSzyfter \& Babula 1996, 1997a,b); Candida, Pichia, Endomyces (Lu et al. 1998) and Debaryomyces (Hsu \& Liu 1994). Also, numerous species of yeast have been isolated from fresh raw seafood products. Of these species, Candida lipolytica, Trichosporon pullulans and T. cutaneum, all having proteolytic activities, have been isolated post mortem from tissues of C. pagurus (Kobatake et al. 1992). Whether these species are native inhabitants of the tissues and haemolymph of $C$. pagurus, or instead are post mortem artefact, remains to be shown. However, it is feasible that under conditions of host immunosuppression (such as that caused by primary disease or by environmental factors), proliferation of native yeast species may produce opportunistic infections in their hosts. When such species have proteolytic or toxic capacities, at least some part of the pathological manifestation associated with the primary disease may otherwise be due to these opportunists. Molecular identification (Fell 1993, Lu et al. 1997) and culture techniques are required to elucidate the identity of the yeast-like organisms detected in $C$. pagurus and $N$. puber from the English Channel and to provide material for transmission studies to determine the susceptibility of compromised and noncompromised hosts.

Acknowledgements. The authors would like to thank Mr. Richard Lord and Mr. Clive Brown for the provision of samples of Cancer pagurus from Guernsey, Professor Keith Vickerman for assistance in the interpretation of ultrastructural material, and the comments of 3 anonymous reviewers. This work was supported by the Department of Environment, Food and Rural Affairs (DEFRA) under contract number F1137. 


\section{LITERATURE CITED}

Arcier JM, Herman F, Lightner DV, Redman RM, Mari J, Bonami JR (1999) A viral disease associated with mortalities of hatchery-reared postlarvae of the giant freshwater prawn Macrobrachium rosenbergii. Dis Aquat Org 38: $177-181$

Bang FB (1983) Crustacean disease responses. In: Provenzano AJ Jr (ed) The biology of Crustacea, Vol 6. Pathobiology. Academic Press, New York, p 113-153

Chen SC, Lin YD, Liaw LL, Wang PC (2001) Lactococcus garvieae infection in the giant freshwater prawn Macrobrachium rosenbergii confirmed by polymerase chain reaction and 16S rDNA sequencing. Dis Aquat Org 45: $45-52$

Chen SN, Kou GH, Ueno Y (1994) Investigation of mass mortality of cultured Macrobrachium rosenbergii in Taiwan. 2nd Int Symp Aquatic Animal Health: Program and Abstracts. School of Veterinary Medicine, University of California, Davis, p w 9.3

Codreanu R, Codreanu-Balcescu D (1981) On two Metschnikowia yeast species producing hemocoelic infections in Daphnia magna and Artemia salina (Crustacea, Phyllopoda) from Romania. J Invertebr Pathol 37:22-27

Colorni A, Diamant A (1992) Pathology in mariculture: specific problems and research in Israel. Isr J Aquac Bamidegh 44: 140

Fell JW (1993) Rapid identification of yeast species using three primers in a polymerase chain reaction. Mol Mar Biol Biotechnol 2:174-180

Field RH, Appleton PL (1995) A Hematodinium-like dinoflagellate infection of the Norway lobster Nephrops norvegicus: observations on pathology and progression of infection. Dis Aquat Org 22:115-128

Field RH, Chapman CJ, Taylor AC, Neil DM, Vickerman K (1992) Infection of the Norway lobster Nephrops norvegicus by a Hematodinium-like species of dinoflagellate on the west coast of Scotland. Dis Aquat Org 13:1-15

Hopwood D (1996) Theory and practice of histopathological techniques, 4th edn. In: Bamcroft JD, Stevens A (eds) Fixation and fixatives. Churchill Livingstone, Hong Kong, p 23-46

Houghton G, Matthews RA (1986) Immunosuppression of carp (Cyprinus carpio L.) to ichthyophthiriasis using the corticosteroid triamcinolone acetonide. Vet Immunol Immunopathol 12:413-419

Hryniewiecka-Szyfter Z, Babula A (1996) Ultrastructural study of pathological effects on the female reproductive system of Saduria entomon L. (Crustacea, Isopoda) from the Baltic infected with Cryptococcus laurentii (Kufferath) Skinner. Invertebr Reprod Dev 29:149-156

Hryniewiecka-Szyfter Z, Babula A (1997a) Ultrastructural changes in the hepatopancreas cells of Saduria entomon (Linnaeus, 1758) (Isopoda, Valvifera) from the Baltic infected with Cryptococcus laurentii (Kufferath) Skinner. Int J Crustac Res 70:822-830

Hryniewiecka-Szyfter Z, Babula A (1997b) Ultrastructural changes in the hindgut cells of Saduria entomon (Linnaeus, 1758) (Isopoda, Valvifera) from the Baltic infected with Cryptococcus laurentii (Kufferath) Skinner. Int J Crustac Res 70:198-205

Hryniewiecka-Szyfter Z, Smith MT, Kaznowski A (1994) Infection of Baltic Saduria entomon (Linnaues, 1758) (Isopoda, Valvifera) with the yeast Cryptococcus laurentii (Kufferath) Skinner. Int J Crustac Res 66:205-211

Hsu JP, Liu CI (1994) Studies on yeast infection in cultured giant freshwater prawn (Macrobrachium rosenbergii).
COA Fisheries Series 47, Fish Disease Research (XV) Taipai 47:55-68

Hudson DA, Lester RJG (1994) A parasitological survey of the mud crab Scylla serrata (Forskal) from southern Moreton bay, Queensland, Australia. Aquaculture 120:183-199

Hudson DA, Shields JD (1994) Hematodinium australis n. sp., a parasitic dinoflagellate of the sand crab Portunus pelagicus from Moreton bay, Australia. Dis Aquat Org 19: 109-119

Johnson PT (1980) Histology of the blue crab, Callinectes sapidus: a model for the Decapoda. Praeger, New York

Johnson PT (1983) Diseases caused by viruses, rickettsiae, bacteria, and fungi. In: Provenzano AJ Jr (ed) The biology of Crustacea, Vol 6. Pathobiology. Academic Press, New York, p 1-78

Kobatake M, Van Rij NJWK, Placido MTLC, Van Uden NV (1992) Isolation of proteolytic psychotrophic yeasts from fresh raw seafoods. Lett Appl Microbiol 14:37-42

Latrouite D, Morizur Y, Noël P, Chagot D, Wilhelm G (1988) Mortalité du tourteau Cancer pagurus provoquee par le dinoflagelle parasite: Hematodinium sp. Cons Int Explor Mer CM 1988/K: 32

Lu CC, Tang FJ, Yoichiro U, Kou GH, Chen SN (1997) Yeast infection in freshwater prawn (Macrobrachium rosenbergii) in Taiwan. Acta Zool Taiwan 8:34-45

Lu CC, Tang KFH, Chen SN (1998) Identification and genetic characterization of yeasts isolated from freshwater prawns, Macrobrachium rosenbergii de Man, in Taiwan. J Fish Dis 21:185-192

Maclean SA, Ruddell CL (1978) Three new crustacean hosts for the parasitic dinoflagellate Hematodinium perezi (Dinoflagellata: Syndinidae). J Parasitol 64:158-160

Messick GA (1994) Hematodinium perezi infections in adult and juvenile blue crabs Callinectes sapidus from coastal bays of Maryland and Virginia, USA. Dis Aquat Org 19: $77-82$

Metschnikoff E (1884) Über eine Sprosspilzkrankheit der Daphnien: Beitrag zur Lehre über den Kampf der Phagocyten gegen Krankheitserreger. Arch Patholog Anat Physiol Klin Med 96:177-195 (English translation)

Meyers TR, Koeneman TM, Botelho C, Short S (1987) Bitter crab disease: a fatal dinoflagellate infection and marketing problem for Alaskan Tanner crabs, Chionoecetes bairdi. Dis Aquat Org 3:195-216

Newman MW, Johnson CA (1975) A disease of blue crabs (Callinectes sapidus) caused by a parasitic dinoflagellate, Hematodinium sp. J Parasitol 63:554-557

Pixell-Goodrich H (1928) Reactions of Gammarus to injury and disease, with notes on some microsporidial and fungoid diseases. Q J Microsc Sci 72:325-353

Reynolds ES (1963) The use of lead citrate at high pH as an electron-opaque stain in electron microscopy. J Cell Biol $17: 208-212$

Ross PS, De Swart RL, Van Loveren H, Osterhaus ADME, Vos JG (1996) The immunotoxicity of environmental contaminants to marine wildlife: a review. Annu Rev Fish Dis 6: 151-165

Shields JD, Squyars CM (2000) Mortality and hematology of blue crabs, Callinectes sapidus, experimentally infected with the parasitic dinoflagellate Hematodinium perezi. Fish Bull 98:139-152

Sindermann CJ (1971) Internal defences of Crustacea: a review. Fish Bull 69:455-489

Smith VJ, Chisholm JRS (1992) Non-cellular immunity in crustaceans. Fish Shell Immunol 2:1-31

Smith VJ, Söderhall K (1986) Cellular immune mechanisms in the Crustacea. Symp Zool Soc Lond 56:59-79 
Sparks AK (1980) Multiple granulomas in the midgut of the Dungeness crab, Cancer magister. J Invertebr Pathol 35: 323-324

Spencer JFT, Phaff HJ, Gardner NR (1964) Metschnikowia kamienskii sp. n., a yeast associated with brine shrimp. J Bacteriol 88:758-762

Stentiford GD, Neil DM, Coombs GH (1999) Changes in the plasma free amino acid profile of the Norway lobster, Nephrops norvegicus at different stages of infection by a parasitic dinoflagellate (genus Hematodinium). Dis Aquat Org 38:151-157

Stentiford GD, Neil DM, Coombs GH (2000) Alterations in the biochemistry and ultrastructure of the deep abdominal flexor muscle of the Norway lobster, Nephrops norvegicus (L.) during infection by a parasitic dinoflagellate of the genus Hematodinium. Dis Aquat Org 42:133-141

Stentiford GD, Chang ES, Chang SA, Neil DM (2001) Carbohydrate dynamics and the crustacean hyperglycaemic hormone $(\mathrm{CHH})$ : effects of parasitic infection in lobsters. Gen Comp Endocrinol 121:13-22

Stentiford GD, Green M, Bateman K, Small HJ, Neil DM, Feist SW (2002) Infection by a Hematodinium-like parasitic dinoflagellate causes Pink Crab Disease (PCD) in

Editorial responsibility: Timothy Flegel, Bangkok, Thailand the edible crab Cancer pagurus. J Invertebr Pathol 79: 179-191

Taylor AC, Field RH, Parslow-Williams PJ (1996) The effects of Hematodinium sp.-infection on aspects of the respiratory physiology of the Norway lobster, Nephrops norvegicus (L.). J Exp Mar Biol Ecol 207:217-228

Taylor DM, Khan RA (1995) Observations on the occurrence of Hematodinium sp. (Dinoflagellata: Syndinidae); the causative agent of Bitter crab disease in Newfoundland snow crab (Chionoecetes opilio). J Invertebr Pathol 65: $283-288$

Thompson SN (1983) Biochemical and physiological effects of metazoan endoparasites on their host species. Comp Biochem Physiol 74B: 183-211

Thörnqvist PO, Söderhäll K (1997) Diseases in Asian aquaculture III. In: Flegel TW, MacRae IH (eds) Crustacean immune reactions, a short review. Fish Health Section, Asian Fisheries Society, Manila, p 203-218

Unestam T (1973) Fungal diseases of Crustacea. Rev Med Vet Mycol 8:1-20

Wilhelm G, Mialhe E (1996) Dinoflagellate infection associated with the decline of Necora puber crab populations in France. Dis Aquat Org 26:213-219

Submitted: August 5, 2002; Accepted: December 4, 2002 Proofs received from author(s): March 20, 2003 